\title{
КІБЕРСОЦІАЛІЗАЦІЯ МОЛОДІ В УМОВАХ ІНФОРМАЦИЙНОЇ ВІЙНИ РОСІЇ ПРОТИ УКРАЇНИ
}

\author{
Наукова доповідь на методологічному семінарі НАПН України \\ «Актуальні проблеми психологічної протидії негативним інформаційним \\ впливам на особистість в умовах сучасних викликів» 8 квітня 2021 р.
}

\section{https://doi.org/10.37472/2707-305X-2021-3-1-13-4}

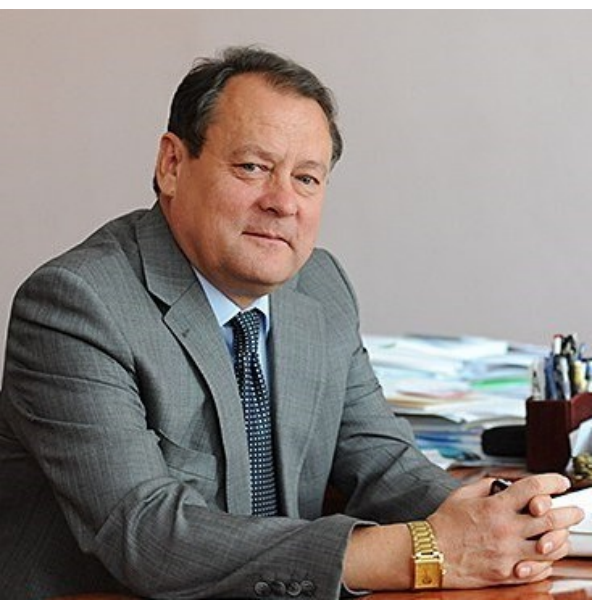

\section{САВЧЕНКО Сергій Вікторович}

доктор педагогічних наук, професор, член-кореспондент НАПН України, ректор Державного закладу «Луганський національний університет імені Тараса Шевченка», м. Старобільськ, Україна

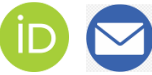
«Луганський національний університет імені Тараса Шевченка», м. Старобільськ, Україна
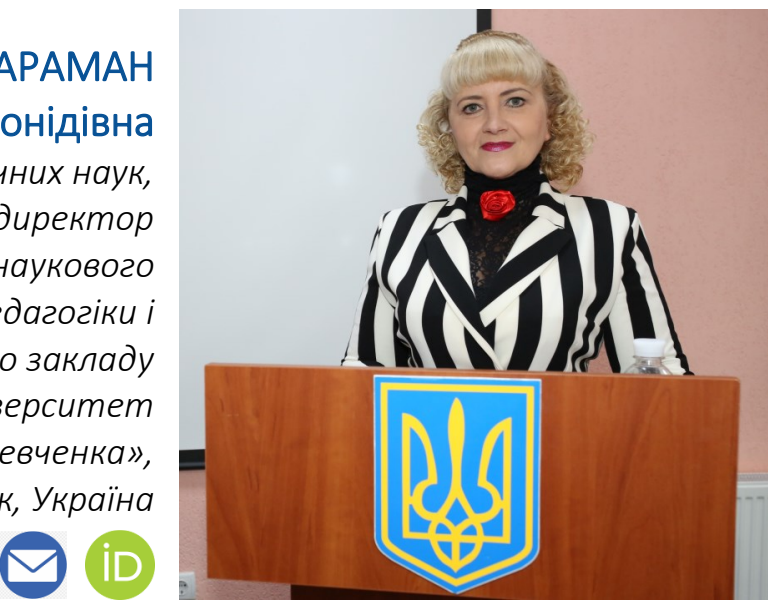

Анотація. У доповіді розкрито сутність та особливості кіберсоціалізації молоді в умовах інформаційної війни Росії проти України. Встановлено, що кіберсоціалізація - це новітній тип соціалізації особистості, прочес розвитку та якісних змін самосвідомості особистості, що відбувається під впливом сучасних інформаційно-комунікаційних технологій. Зроблено висновок щодо необхідності цілеспрямованого впливу на кіберсоціалізацію молоді з метою супротиву інформаційній війні Росії проти України. Наведено досвід реалізації проєкту "Університетська телерадіостудія як засіб фрормування українського молодінного медіапростору регіону» в Луганському національному університеті імені Тараса Шевченка.

Ключові слова: кіберсочіалізачія; молодь; інформачійна війна; медіапростір; соиіально-педагогічний супротив.

Сучасна молодь постіндустріальної епохи проходить школу соціального становлення за допомогою посередника - комп'ютера, що істотно змінює характер і напрям соціалізації. Останніми десятиліттями інформаційно-комунікаційні технології стали одним із найважливіших чинників, які впливають на інформаційне суспільство, ключовою ланкою науково-технічного й інноваційного розвитку.

Це породжує небезпеку маніпулювання свідомістю й поведінкою людини, загрожує масштаб- ною дегуманізацією. Але для України ця глобальна небезпека має свої особливості, оскільки наша держава вже кілька років поспіль перебуває у стані війни, зокрема інформаційної, розв'язаної Росією проти України. Головними жертвами інформаційного впливу Російської Федерації на Україну стають люди малоосвічені й недосвідчені, насамперед, молодь.

Отже, перед закладами освіти України різних рівнів постає завдання з організації соціальнопедагогічного спротиву інформаційному впливу 


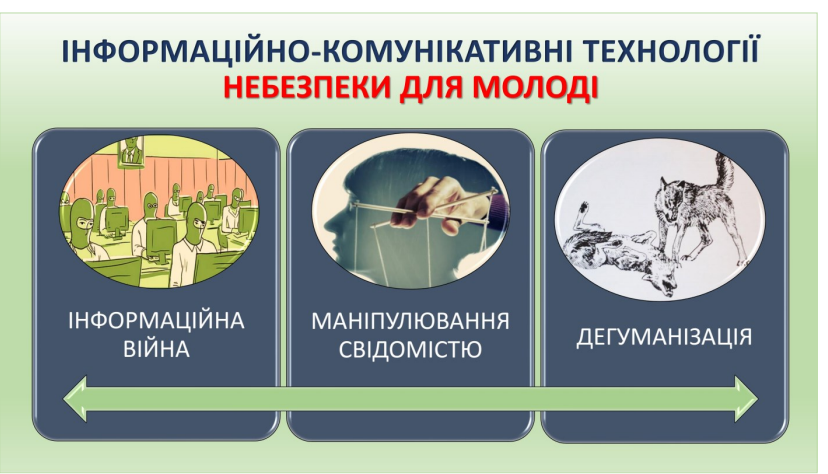

Російської Федерації на нашу країну, створення простору для розвитку інформаційної культури особистості та її кіберсоціалізації.

За час війни на сході України вітчизняна наука збагатилася чималою кількістю досліджень, предметом яких $€$ безпосередньо гібридна війна, її причини, основні ознаки, складники, форми та методи ведення (А. Бадер, Ф. Брицко, В. Богайчук, Л. Будагьянц, В. Горбулін, С. Дацюк, С. Корнієнко, Є. Магда, В. Осьодло, В. Панченко, Г. Почепцов, Ю. Радковець, С. Савченко, В. Толубко, В. Черниш, О. Цуканова та ін.). Ученими встановлено, що гібридна війна - це війна з поєднанням принципово різних типів і способів її ведення:

1) класичних прийомів з використанням збройних сил і військової техніки;

2) використання нерегулярних збройних формувань (ополченців, бойовиків, «зелених чоловічків» тощо);

3) інформаційних технологій.

Сутність, особливості, технології ведення інформаційної війни та ії психологічного впливу на населення відображено в наукових працях таких учених, як Ю. Бабенко, В. Богуш, Л. Будагьянц, В. Вінтоняк, І. Воробйова, К. Гринько, В.Гурковський, А. Дубина, О. Караман, І. Костюк, В. Курило, Н. Марута, М. Маркова, В. Осьодло, В. Панченко, В. Петрик, С. Савченко, О. Саєнко, В. Третьякова, П. Шевчук, П. Шпига та ін.

Розкриттю психологічних механізмів маніпулювання масовою та індивідуальною свідомістю населення в умовах гібридної війни на сході України присвячено наукові розвідки О. Гойман, В. Гурковського, А. Дубини, Р. Колеснікової, І. Кононова, Н. Марути, М. Маркової, Ю. Мороза, Д. Прокоф'єва, О. Саєнка, В. Хорошка, А. Чантурії та ін.

Безпосередньо проблемі кіберсоціалізації (та ії синонімічним аналогам - медіасоціалізації, інфосоціалізації, цифросоціалізації тощо, семантичну специфіку яких треба уточнювати) присвячено студії таких науковців, як О.Городецька, M. D`Amato, О. Зінчина, О. Караман, І. Кіндрат,

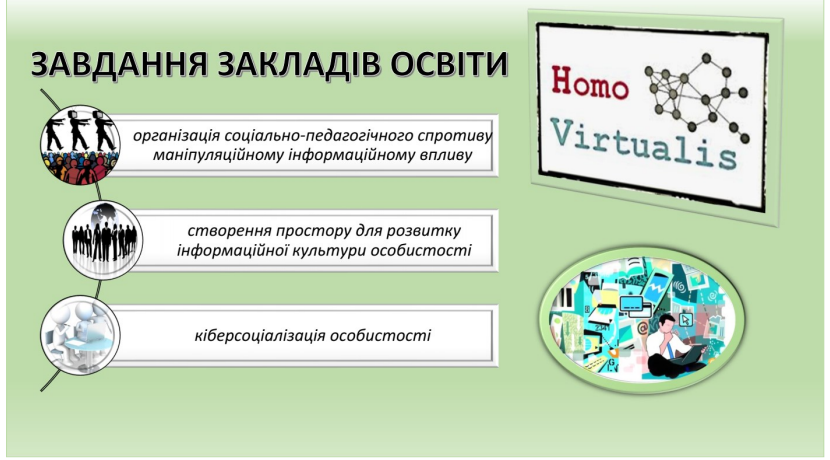

В. Конах, В. Курило, Г. Лещук, М. Маклюэн, М. Матвійчук, М. Наумова, О. Петрунько, С. Савченко, С. Семчук, А. Тадаєва, М. Hota, M. Shahid та ін.

Під кіберсоціалізацією ми розуміємо новітній тип соціалізації особистості, який $€$ процесом розвитку та якісних змін самосвідомості особистості, що відбувається під впливом й внаслідок використання людиною сучасних інформаційнокомунікаційних, комп'ютерних, електронних, цифрових, мультимедійних, мережевих та інтернет-технологій. Сьогодні конструюється новий тип соціального індивіда homo virtualis - людина, орієнтована на віртуальність; творець, носій, та споживач віртуальної культури.

Уже беззаперечним є той факт, що інформаційна війна Росії проти України - це війна із використанням переважно інформаційної зброї, тобто інформаційних технологій, які базуються на брехні, напівправді, поширенні чуток, неправди вих версій, придуманих подій та їх обманних інтерпретацій. Це тотальне нав'язування населенню, а головне - молоді, агресивної антиукраїнської інформації. У цій інформації чітко простежуються історичні, політичні, економічні, культурні, соціальні аспекти. Вони різняться за своїми масштабами, обсягами, рівнем брехні та цинізму, спрямованістю на різні верстви населення тощо. Проте об'єднує їх одна глобальна мета - формування у молоді негативного ставлення до України, її історії, традицій, навіювання почуття зневіри в перемогу, безвиході, відсутності перспективи тощо. Фактично наш ідеологічний противник ставить перед собою завдання управління життєвими цінностями, смислами і цільовими установками української молоді, підміняючи природні для нашого народу зразки на помилкові деструктивні ідеали.

Отже, можемо стверджувати, що об'єктом, на який спрямовано основний удар інформаційної війни, є психіка людини, особливо молодої людини, недосвідченої, некомпетентної, що не має достатнього життєвого досвіду, щоб самостійно розібратися у хитросплетіннях сучасного життя. За 
мету обрано зміну свідомості молодого покоління; основними механізмами - труднощі в доступі до правдивої інформації і нав'язування ворожого інформаційного продукту, а очікуваний результат лежить у площині прийняття рішень. І це ми повною мірою спостерігаємо на прикладі молодого покоління окупованого Донбасу, яке під впливом російської пропаганди та продажних місцевих 3Ml активно вступає до лав ополченців, бере участь в антиукраїнських мітингах, сповідує чужі нам цінності, слідує за чужими ідеалами.

Водночас слід визнати, що російська пропагандистська машина особливою різноманітністю форм і методів роботи не відрізняється. На відміну від внутрішнього споживача - російських громадян - тут в основу покладено старі та перевірені часом принципи геббельсівської пропаганди, а саме: інтелектуальне спрощення, обмеження фактичного матеріалу, фільтрація невигідної інформації, настирливе повторення основних тез та емоційне нагнітання. При цьому фундамент цього нехитрого пропагандистського набору становить брехня. I не просто брехня, а брехня величезна, жахлива, адже саме тоді люди вірять в неї. Особливо небезпечна така пропаганда для підлітків і молоді нашої країни.

Які ж прийоми інформаційної війни найбільш часто використовуються для впливу на молодь?

Назвемо деякі з них:

- замовчування і спотворення історичних фактів;

- нав'язування чужих ідей, цінностей;

- зниження значущості подій, знецінення досягнень;

- маніпулювання свідомістю;

- програмування поведінки;

- заміна позитивних образів реальних героїв вигаданими неіснуючими зразками;

- знецінення героїчних вчинків;

- штучне створення негативного образу лідера за рахунок знецінення його заслуг і багато чого іншого.

Що можливо й необхідно цьому протиставити?

В основу контрпропагандистської діяльності, метою якої $є$ зниження і нівелювання негативних впливів російських медіатерористів на особистість, має бути покладено науковий підхід. Боротьба за уми та світогляд юних українців повинна спиратися на найпередовіші ідеї вітчизняної соціальної педагогіки та психології. Будь-які спроби протистояти професійним зусиллям російських медіатерористів на рівні аматорської самодіяльності

\section{КОНТРПРОПАГАНДИСТСЬКА ДІЯЛЬНІСТЬ}

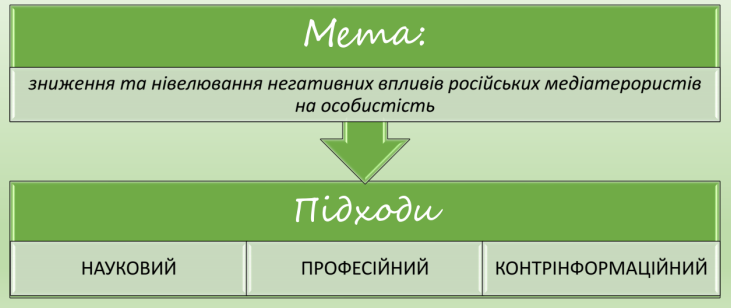

будуть приречені на провал. Контрпропаганда, як і контрінформаційний супровід особистості, вимагають не менш професійних підходів та фахівців. У зв'язку з цим у закладах вищої освіти України необхідно почати підготовку кадрів не тільки для засобів масової інформації, а й для ефективного протистояння масовій дезінформації.

Загалом, визначаючи роль засобів масової інформації у процесі кіберсоціалізації молоді в умовах інформаційного суспільства, можна зробити висновок, що ЗМІ та Інтернет є засобами формування «моделей» соціальної реальності, найважливішим джерелом нормативних зразків, що циркулюють у суспільстві.

Актуальність інформаційної соціалізації молоді визначається складністю сучасної суспільної ситуації в Україні. Розпалися раніше створені молодіжні об'єднання й організації, молоді люди опинилися сам на сам, почався процес десоціалізації, який призвів до значного зростання числа молоді з девіантною поведінкою.

Такі обставини вимагають активізації діяльності вчених, педагогів-практиків щодо соціалізації молоді загалом та її кіберсоціалізації зокрема, а також виховання у молоді громадянських якостей. Велике значення для вирішення цієї проблеми приділяється підвищенню освітнього рівня молоді, у тому числі формуванню інформаційної культури особистості. У зв'язку з цим необхідні заходи щодо організації навчальних 3MI та Інтернет-ресурсів.

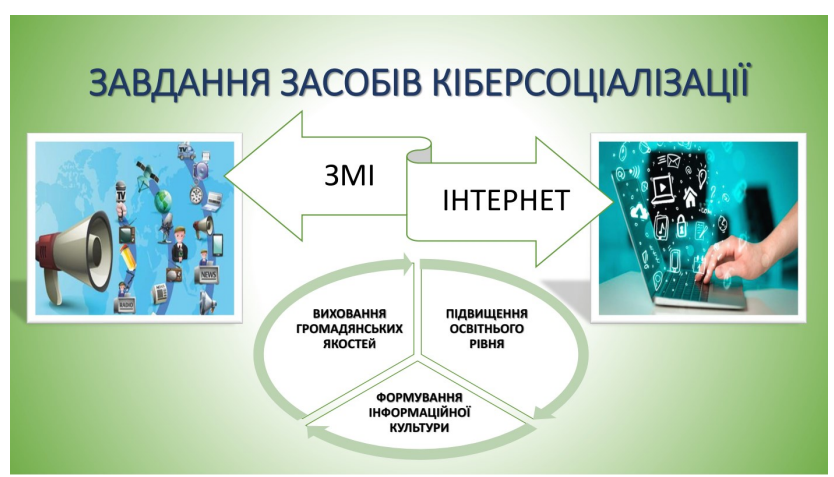




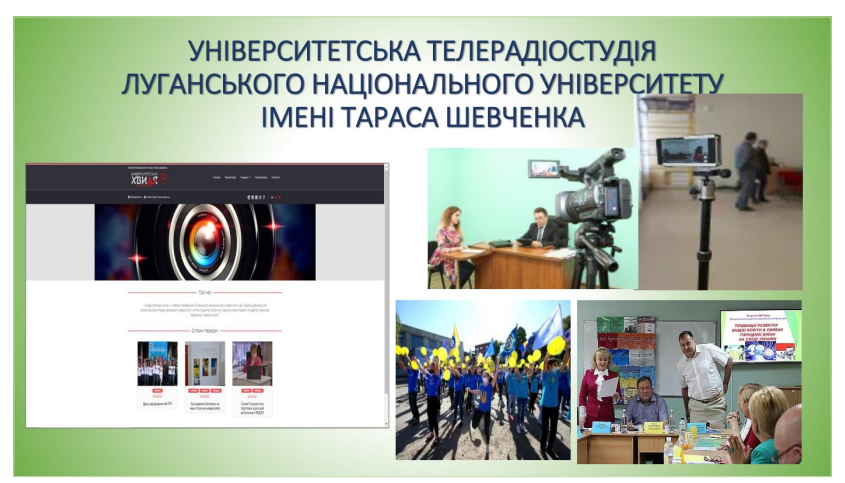

Цікавим прикладом успішної реалізації поставленого завдання $€$ діяльність Університетської телерадіостудії Луганського національного університету імені Тараса Шевченка.

Вона була створена в 2020 р. у рамках проєкту під назвою «Університетська телерадіостудія як засіб формування українського молодіжного медіапростору регіону». Реалізований проєкт доповнив уже існуючу на той час онлайнрадіостанцію «Університетська хвиля», яка розпочала свою роботу в травні 2017 р. Телестудія дає змогу не тільки якісно готувати журналістівпрактиків, а й практикуватись у навичках протидії російській інформаційній агресії.

\section{СПИСОК ВИКОРИСТАНИХ ДЖЕРЕЛ}

Баришполець, О.Т., Голубєва, О.Є., Климчук, Н.В., Мироненко, Г.В., Найдьонова, Л.А., Різун, В.В., Сергійчук, Г.В., Стерденко, С.М., Стрільчук, О.М., \& Череповська, Н.І. (2009). Медіакультура особисmості: соціально-психологічний підхід : навчальнометодичний посібник (Л.А. Найдьонова, О.Т. Баришполець, ред.). Київ: Міленіум. http:// mediaosvita.org.ua/book/mediakultura-osobystostisotsialn/

Городецька, О. (2018). Вплив медіа-інформаційних технологій на процес соціалізації дітей дошкільного віку. Нова педагогічна думка, (3), 166-169. http://nbuv.gov.ua/UJRN/Npd_2018_3_37

Зінчина, О. (2017). Медіасоціалізація сучасної молоді: виклики і відповіді. Вісник Харківського національного університету імені В.Н. Каразіна. Серія «Сочіологічні дослідження сучасного суспільства: методологія, теорія, методи», 39, 332-339. https:// periodicals.karazin.ua/ssms/article/view/10283

Іванов, В.Ф., \& Волошенюк, О.В. (ред.-упор.). (2012). медіаосвіта та медіаграмотність : підручник (В.В. Різун, наук. ред.). Київ: Центр вільної преси. https://www.aup.com.ua/uploads/momg.pdf

Кіндрат, І.Р. (2013). Вплив сучасного медіа-простору на формування світоглядних уявлень дитини дошкільного віку. Вісник Луганського начіонального університету імені Тараса Шевченка. Педагогічні науки, (13), 94-101. http://nbuv.gov.ua/UJRN/ vlup_2013_13\%283\%29_15

Конах, В.К. (2015). Виникнення та еволюція поняття «медіапростір» у науковій думці. Вісник Дніпропет-
ОНЛАЙН-РАДІОСТАНЦІЯ «УНІВЕРСИТЕТСЬКА ХВИЛЯ»

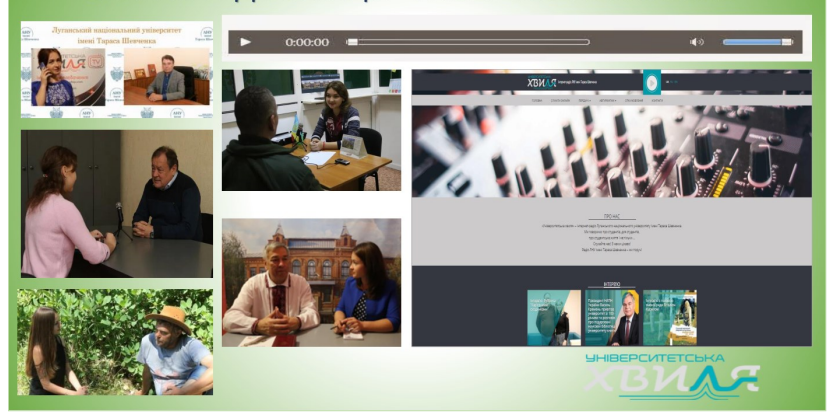

ровського університету. Серія: Філософрія. Соціологія. Політологія, (2), 112-129. https:// visnukpfs.dp.ua/index.php/PFS/article/view/689

Курило, В.С., Савченко, С.В., \& Караман, О.Л. (2018). Соціалізація особистості в умовах гібридної війни на сході України : монографія. Київ: Талком.

Курило, В.С. (2019). Медіасоціалізація як складник соціалізації особистості в інформаційному суспільстві. Вісник Луганського національного університету імені Тараса Шевченка. Педагогічні науки, $(1,4.1)$, 83-89. https://doi.org/10.12958/2227-2844-2019-1 (324)-1-83-89

Лещук, Г. (2014). Вплив засобів масової інформації на процес соціалізації підлітків. Молодь і ринок, (3), 76-80. http://nbuv.gov.ua/UJRN/Mir_2014_3_17

Маклюэн, Г.М. (2003). Понимание медиа: внешние расширения человека (В. Николаева, пер. с англ.). Москва; Жуковский: «КАНОН-пресс-Ц», «Кучково поле».

Матвійчук, М.М. (2014). Формування медіаграмотносmі майбутніх соціальних педагогів у процесі фахової підготовки. (Автореф. дис. канд. пед. наук). Національний педагогічний університет імені М.П. Драгоманова, Київ.

Наумова, М. (2011). Нові медіа та традиційні 3МІ: моделі співіснування. Актуальні проблеми соціології, психології, педагогіки, (13), 86-92. http:// nbuv.gov.ua/UJRN/apspp_2011_13_16

Петрунько, О. (2010). Діти і медї: соціалізація в агресивному медіа середовищі : монографія. Полтава: ТОВ НВП «Укрпромторгсервіс».

Семчук, С.І. (2011). Особливості впливу засобів масової інформації на соціалізацію дітей дошкільного віку. (Автореф. дис. канд. пед. наук). Уманський державний педагогічний університет імені П. Тичини, Умань.

Тадаєва, А.В. (2016). Сочіально-педагогічний супровід сочіалізації молодших школярів в сучасному інформаційному просторі. (Дис. канд. пед. наук). Харківська державна академія культури, Харків.

Hota, M., \& McGuiggan, R. (2005). The Relative Influence of Consumer Socialization Agents on Children and Adolescents - Examining the Past and Modeling the Future. In K.M. Ekstrom, H. Brembeck (Eds), E European Advances in Consumer Research, 7 (pp. 119124). https://www.acrwebsite.org/volumes/13831/ eacr/vol7/E-07

Shahid, M. (2013). Role of media in political socialization of young generation. American Based Research Journal, 2(1), 56-61. 
CYBERSOCIALIZATION OF YOUTH UNDER RUSSIA'S INFORMATION WARFARE AGAINST UKRAINE

Scientific report at the methodological seminar of the National Academy of Educational Sciences of Ukraine

"Actual Problems of Psychological Resistance to Harmful Information Impact on Personality under Current Challenges" (April 8, 2021)

Serhii Savchenko

DSC in Pedagogy, Professor, Corresponding Member of NAES of Ukraine, Rector, State Institution "Luhansk Taras Shevchenko National University", Starobilsk, Ukraine

\section{Olena Karaman}

DSC in Pedagogy, Professor, Director of Training and Research Institute for Pedagogy and Psychology, State Institution "Luhansk Taras Shevchenko National University", Starobilsk, Ukraine

Abstract. The report reveals the essence and features of cybersocialization of youth under Russia's information warfare against Ukraine. It is established that cybersocialization is the newest type of personality socialization, the process of development and qualitative changes of personality self-consciousness, which takes place under the influence of modern information and communication technologies. It is concluded that it is necessary to purposefully influence the cybersocialization of young people under Russia's information warfare against Ukraine. The experience of project "University TV and Radio Studio as a Means of Forming the Ukrainian Youth Media Space of the Region" at the Luhansk Taras Shevchenko National University is presented.

Keywords: cybersocialization; youth; information warfare; media space; social and pedagogical resistance.

Дата публікації: 15 квітня 2021 р. 